\title{
A Review of Big House on the Prairie: Rise of the Rural Ghetto and Prison Proliferation, by John M. Eason
}

\author{
The University of Chicago Press, 2017, 240 pages \\ ISBN (paper): 9780226410340
}

\section{Review by Rayna E. Momen \\ West Virginia University, Morgantown, WV. USA}

In this era of mass incarceration, where the United States represents five percent of the world's population, yet houses twenty-five percent of the world's incarcerated individuals, new prisons have been constructed in rapid numbers. Examining the causes and consequences of this rapid prison expansion that resulted in triple the number of new prisons in the period from 1970 to 2000, is thus of critical importance. John M. Eason's ethnography, Big House on the Prairie: Rise of the Rural Ghetto and Prison Proliferation offers important insights into this phenomenon, as demonstrated by his research in a rural Arkansas town faced with the obstacles of seeking and securing a prison facility.

Prior work as a community and political organizer adds to his repertoire of knowledge about this important area of study. Much of his work has focused on exploring avenues for social change through policy initiatives. Eason's research in the areas of race, crime, punishment, and health, and his work in both rural and urban sociology, informs his critiques of the nascent literature on this under examined topic. $\mathrm{He}$ offers a unique perspective on the relationship between place, race, disadvantage, and the criminal justice system, which has wider implications for the fields of sociology, criminology, and criminal justice more broadly.

In Big House on the Prairie, Eason suggests that a rural-centered perspective is requisite to understanding the causes and consequences of the prison boom, primarily due to the concentration of new prisons in largely rural, southern towns, populated with a greater proportion of African Americans and Latinos. The rural prison boom thus has important social, economic, and political ramifications. Further, Eason emphasizes the role of the rising rural ghetto, as well as the stigmas associated with communities suffering from concentrated poverty and cumulative disadvantage, suggesting that these factors serve as a catalyst for why this particular rural town, and many others like it, came to demand a prison. In sum, he suggests that rural prison siting is multifaceted and that the nuanced factors cannot be oversimplified. To overcome the spoiled identity associated with many rural towns, due to flailing economies that resulted from deindustrialization, globalization, the mechanization of farming, as well as the 'Post-Jim Crow' era, the perception of prisons appears to have shifted from stigmatized institutions 
to promising public works projects, although the impacts of prison siting are arguably less favorable.

The book opens with a glossary of relevant terms to help situate the argument, which aids the reader in understanding what the penal- and prison-industrial complex is more broadly. Terminology specific to prison placement, construction, expansion and its impacts, and what it means to be a prison town, inform an introductory look at the causes and consequences of the prison boom. The remainder of the book is broken down into two parts. Part one focuses on prison placement, particularly, the making of the rural ghetto and the shift from Not In My Backyard (NIMBY) to Please In My Backyard (PIMBY), despite such stigmatized institutions typically being seen as locally undesirable land uses (LULUs). In this section, Eason outlines the development of his model on prison placement, which frames his analysis of prison impact on the political economy, the focus of part two.

Eason's book is the product of an ethnographic case study of Forrest City, Arkansas, for which he incorporated interviews, archival research, participant observation, mapping, and statistical data analysis. This multi-method research was heavily focused on observation. Although he and his family entered the town as outsiders, Eason was able to establish a rapport with local residents through established key informants, as well as key stakeholders - both white elites and race leaders - who formed a growth coalition to spark the campaign to acquire a prison in their town. Gaining access to the heart of the community, while maintaining social distance, allowed him to recognize emergent themes that might otherwise have been overlooked, such as the rise of the rural ghetto and its role in rural prison proliferation. Through formal and informal interviews with key decision makers and community members, he constructed a social history of the town. He also utilized data from local, state, and federal agencies to employ quantitative and descriptive analysis. With this mixed method approach, Eason devises a framework for understanding the causes and consequences of rural prison siting.

This book offers a refreshing move away from the mostly urban-centric view of mass incarceration that dominates the extant research, which is perhaps its greatest strength. In addition to the importance of the rural context (especially the broader historical context), the role of stigma, as well as locals' perceptions of the how the prison has impacted this community were well received. At the same time, concerns about the way incarcerated people are referenced, the theoretical argument he puts forth, as well as his emphasis on the benefits of prison siting, are points of contention.

Throughout the book, Eason uses terms such as 'inmates' and 'prisoners.' Many 
people have sought to change this problematic language. To better humanize this population, phrases such as 'people currently or formerly incarcerated' are suggested (Ellis, 2005). With respect to theory, Eason is highly critical of a Marxian analysis for understanding rural prison proliferation, and while he offers an alternative approach, shaped by a Weberian perspective, his argument is less convincing.

Eason also suggests that prisons impact host communities in both positive and negative ways. However, he critiques the nascent literature for focusing primarily on the negative impacts on the political economy of rural towns, but fails to counter this with supporting evidence. In fact, he makes a rather staunch claim that seems to discount the work of prior scholars. Eason (2017) states:

There is no evidence supporting the claim that prison building has negative consequences on rural communities. We should therefore consider the prison as a stabilizing force for rural communities headed toward the precipice of economic and social despair (p. 170).

One can easily offer evidence illustrating the negative impact of prisons on rural communities, some of which is put forth by Eason himself. As such, the above claim is confusing in its placement and presence in this ethnography.

Moreover, the author argues that prison siting positively impacts racial and ethnic minorities, but the reasons are far from compelling. For example, Eason (2017) asserts:

If prison building could simply be explained as a function of urban economic and racial stratification, then how can we reconcile the benefits prisons provide to rural communities of color? A fair number of prison jobs go to people of color in rural communities. For example, in 2000, African Americans and Latinos respectively made up 22 percent and 7 percent of correctional officers in the United States (Ward, 2006). The presence of a significant number of blacks and Hispanics in correctional officer positions in rural communities complicates a central theme of racial dominance in the prison boom literature. In addition to social control, poverty management, racial exploitation, and stigma, prisons appear to offer jobs to disadvantaged rural communities of color (p. 171).

Yet, stating that some racial and ethnic minorities have obtained positions as correctional officers in rural places does not easily translate to seeing rural prison siting as a benefit to people of color. 
In sum, this ethnography adds to the extant literature on rural prison proliferation. While geared toward a more conservative audience, prison abolitionists, laypeople, and other scholars may benefit from the perspectives that residents of a rural prison town have to offer, and will perhaps gain a more objective understanding of why and how rural towns come to reshape their view of such stigmatized institutions into potential panaceas during times of severe economic decline.

\section{References}

Ellis, E. (2005). An open letter to our friends on the question of language. Center for NuLeadership on Urban Solutions. Retrieved from https://cmjcenter.org/wpcontent/uploads/2017/07/CNUS-AppropriateLanguage.pdf

Ward, G. K. (2006). Race and the justice workforce. In R.D. Peterson, L.J. Krivo, \& J. Hagan (Eds.), The many colors of crime: Inequalities of race, ethnicity, and crime in America (pp. 67-89). New York University Press. 